\title{
Supplier Selection Using Analytical Hierarchy Process at PT. Indolakto
}

\author{
Putri Candra Anggani, Imam Baihaqi dan Dewanti Anggrahini \\ Business Management Department, Faculty of Industrial Technology, Institut Teknologi \\ Sepuluh Nopember (ITS) \\ Jl. Arief Rahman Hakim, Surabaya 60111 Indonesia \\ e-mail: ibaihaqi@mb.its.ac.id
}

\begin{abstract}
Abstrak-Dairy supply chain is one of food supply chain that has its own uncertainty both in upstream and downstream process due to the durability of product. Dairy market has good demand trend, because the supply is still below the consumption level. Indonesia use imported dairy product rather than use the domestic ones, because the supply of domestic dairy still below the demand. So, there are opportunities for dairy company to compete in this industry and reach competitive advantage by solving the upstream problems. Selecting supplier is one of upstream supply chain area which affected the quality of dairy product and mitigate supply chain risk management from the beginning. This research aim to develop a framework for supplier selection. According to AHP method this research will be determine main criteria by interview, pair wise comparison on developing the AHP, determine sub criteria based on main criteria, and rank the supplier. The result is forming a framework of supplier selection based on company requirements. Also, the main criteria for supplier selection are quality, quantity, delivery, warranty, and pricing with sub main criteria which already deployed. Maltodextrin A will be choose rather than Maltodextrin B. The sensivity analysis also shown that all of criteria were robust.
\end{abstract}

Kata Kunci- AHP, Dairy Supply Chain, Supplier Selection, Supply Chain Risk Management..

\section{INTRODUCTION}

$\mathrm{D}$ AIRY supply chain is a kind of food supply chain. Food supply chain has its own volatility of products because of the natural attributes which has impact on customer's health. The food industry has its own uncertainty both in upstream and downstream process [1],[2]. In upstream, there are some uncertainty of supply due to some reasons. Chen and Guo (2013), argue that the uncertainty of supply is caused by the difference of product quality on each supplier and different pricing due to currency [3]. Based on Pujawan (2010), the uncertainty of supply due to some reason, such as the seasonal of raw material, the capacity of supplier, delivery lead time by supplier and the quantity of available material [4]. In downstream, there are several problems which affect the uncertainty of food supply chain. Dani (2015) argued that food industry deals with uncertainty due to the durability of food product. The life time of food product is limited by period of time [5]. The uncertainty of customer demand and the capacity of warehouse also becoming one of this problem [4]. Currently, product safety and health becoming consumer awareness [6]. For this industry, if a company can survive and dealing with these situations, it will give them competitive advantage.

Dairy market have a good trend, because the supply is still below the consumption level. According to Global Business Guide Indonesia (2015), domestic stock only fulfill fifth of national demand per year [7]. A research have done by Ministry of Industry, the demand of dairy products in Indonesia almost 3.3 million tonnes per year, but Indonesia importerd more than $70 \%$ in 2009 [7]. There are some raw material such as skim milk powder that have to be imported. These imported material come from Australia, New Zealand, United States, and Europe. As domestic market fails to fulfill the demand, local industries choose to use imported milk.

In supply chain, selecting supplier needs time and resources, especially for the main supplier that supplying for the main product [4]. Chen and Guo (2013), conducted a research the analysis of supplier selection benefits are mitigate supply chain risk, increasing competitive advantage, and forming strategies for company [3]. Supplier selection also helping decision makers to make decisions. Only choose the important one and related to the problems [8]. AHP could integrate between the existing condition of the company and criteria which company really needs to be developed [8].

The existing condition at PT. Indolakto - Purowsari based on PPIC manager and Purchasing supervisor is using another form of supplier selection. Also, this company using level of approval as standard of supplier selection. This standard is used based on main company of Indolakto. There are only two scale which are the supplier doing performance or not. This scale is still too general for supplier selection. Besides, there are only main criteria on their form. So, for detail information on supplier selection and developing their supplier performance become easier, this report identify each sub criteria of their main criteria. This research will forming supplier selection form using AHP method at PT. Indolakto - Purwosari. Knowing main and sub criteria for supplier selection, selecting the right supplier, and doing the sensitivity also becomes objective in this research. Supplier selection will be adapted as company needs.

\section{LITERATURE REVIEW}

\section{A. Dairy Supply Chain}

Dairy supply chain or food supply chain have different 
characteristic from other supply chain due to product freshness change overtime, process, and information flow to supply chain actors [9]. According to Aung et al (2014), dairy supply chain is a process with six main activities such as the production of raw milk into dairy product, transportation of the product, processing, packaging the product that match with the characteristic of product, storage and consumption by consumer [1].

\section{B. Supplier Selection and Supplier Performance Evaluation}

According to Beil (2009), supplier selection have three main steps, which are identify, evaluate and contract [10]. Getting information from suppliers that refer to company needs for identifying potential suppliers, setting and negotiating contract, and evaluating their performance. Based on Weber et al (1991) argued that price, on time delivery, quality of resources, and production ability are four categories for selecting supplier [11]. Dickson (1966) mentioned that there are 23 criteria for supplier selection [12].

Based on Dey et al (2014), supplier performance evaluation is needed for organisational system for measuring supplier performance effectively [13]. Supplier performance is one of mitigate system for manufacturing organisation especially in procurement.

\section{Risk Management}

COSO (2004), argued that risk is related to impact of negative events and possibility of having unwanted events [14]. There are four categories of risk based on $\mathrm{Wu}$ et al (2008). Risk as hazard, possibility, consequence, and potential adversity or threat [15].

\section{Supply Chain Risk Management}

Wu et al (2008), considered supply chain risk management focus on relation between each organizational processes to identify the goals and mitigate the risk of uncertainty events [15]. There are four process of supply chain risk management which are risk identification, risk assessment, risk avoidance, and risk mitigation.

\section{E. Analytical Hierarchy Process (AHP)}

AHP theory was found by Saaty (1980). Saaty implied on his research (2008), decision making is fundamental things after getting the right information [8]. Not all of information is used, only the important ones. Making decision is better if all aspects are transparent. It is involves a lot of criteria and sub criteria refer to company requirements. Priority of many options will be discovered as a decision. Here are the following steps for AHP :

1) Determine the problem and sources of information

2) Making structure of decision hierarchy with the goals on top, the objective, and how to accomplish the goals.

3) Setting comparison matrices. Each criteria in the upper level will be compare to the immediate level.

4) Priorities needs for comparing the priorities using fundamental scale.
Table 1.

Fundamental sale

\begin{tabular}{|c|c|c|}
\hline $\begin{array}{l}\text { Intensity of } \\
\text { Importance }\end{array}$ & Definiton & Explanation \\
\hline 1 & Equal Importance & $\begin{array}{l}\text { Two activities contribute equally } \\
\text { to the objective }\end{array}$ \\
\hline 2 & Weak or slight & \\
\hline 3 & $\begin{array}{l}\text { Moderate } \\
\text { importance }\end{array}$ & $\begin{array}{l}\text { Experience and judgement } \\
\text { slightly favour one activity over } \\
\text { another }\end{array}$ \\
\hline 4 & Moderate plus & $\begin{array}{l}\text { Experience and judgement } \\
\text { strongly favour one activity over }\end{array}$ \\
\hline 5 & Strong importance & another \\
\hline 6 & Strong plus & \\
\hline 7 & $\begin{array}{l}\text { Very strong or } \\
\text { demonstrated } \\
\text { importance }\end{array}$ & $\begin{array}{l}\text { An activity is favoured very } \\
\text { strongly over another, it is } \\
\text { dominance demonstrated in } \\
\text { practice }\end{array}$ \\
\hline 8 & Very, very strong & \\
\hline 9 & Extreme importance & $\begin{array}{l}\text { The evidence favouring one } \\
\text { activity over another is of the } \\
\text { highest possible order of } \\
\text { affirmation }\end{array}$ \\
\hline
\end{tabular}

\section{F. Research Gap}

This observation refers to those journals. There are several journals that only focus on dairy supply chain. Others focus on supplier selection using AHP method. Researcher will combine those research into designing supplier selection with AHP that fulfilling company requirement.

There are two elements which are supplier selection, and dairy supply chain. Supplier selection is adopted by Dweiri et al (2016) and Bruno et al (2012). While Dairy supply chain deployed form Pant et al (2015) and Bourlakis et al (2013).

\section{RESEARCH METHODOLOGY}

This research belong to case study empirical research (Flynn et al, 1990) as it will draw data from the company and will be analyzed to derivat recommendation [16]. Data will be gathered through interviews with key managers as well as small questionnaire. As explained in the previous chapter, this research will largely follow the methodology set out in AHP.

This framework explain about determining main and sub criteria for supplier selection until selecting supplier based on AHP method. Interview is conducted for selecting main criteria refer to company requirements. After selecting main criteria, AHP model is developed and create questionnaire for pair wise comparison based on experts assessment. This steps is repeated for selecting and pair wise comparison sub criteria. Using AHP method, rank the supplier with AHP wise comparison. 


\section{DATA ANALYSIS AND DisCUSSION}

\section{A. Identifying Main and Sub Criteria for Supplier Selection}

Depth interview is conducted for identifying main and sub criteria for supplier selection. There are several main criteria and sub criteria for supplier selection, but as the progress is running, some of them are added or deleted due to experts point of view. Shapiro (2014) state that criteria for supplier selection or supplier performance evaluation is reflect on company condition, not just according to theory [17].

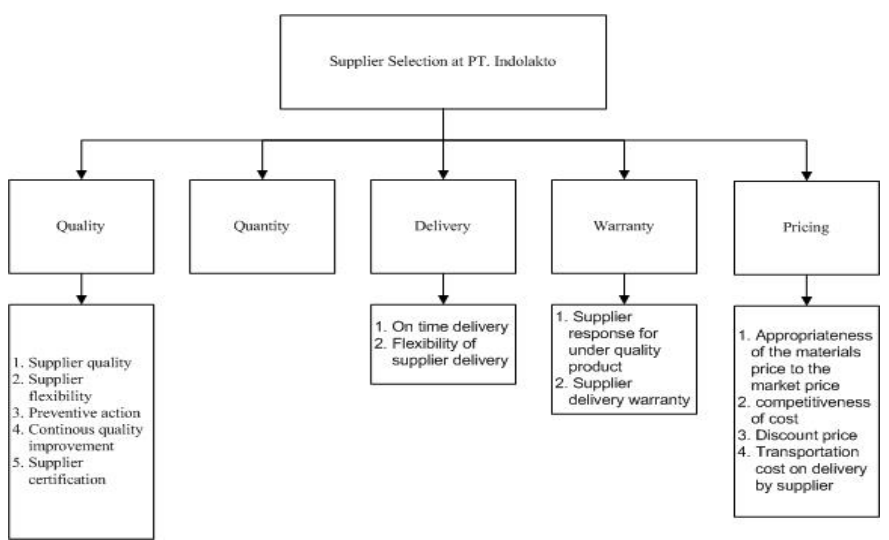

Figure 1. Final criteria after validation

Quality is important due to the characteristic of dairy material or product. It is affected by the product freshness and durability of dairy product. The life time of dairy product is limited by period of time [9;5]. During the interview with expert at PT. Indolakto, quality becoming the most important criteria rather than others because the quality will affect the taste and life time of their product. If the quality is under the standard of Indolakto's R\&D, then it will reduce the product life time or ruin the product itself. Constantly, the cost will increase due to this problem, the warehouse schedule must be re-schedule due to fail products turnover, and consumer satisfaction will be decrease. If consumer satisfaction decrease, Indolakto's products will be untrusted. Indolakto apply ISO 9001:2008 for quality management, so this company consider quality as important aspect. Delivery become one of supplier selection criteria based on Weber (1991). Dairy industry need material dairy product which are have their expired time. Because of the durability of dairy material, so the delivery must be on time. Beside, warehouse capacity is limited, so if delivery is not on time, then the warehouse schedule must be reschedule. Quantity of dairy material supply is under the demand. So, it is important for supplier to fulfill the right amount of dairy material as company need. Pricing also one of supplier criteria based on Dickson (1966). Usually supplier already have price which are competitive on each other. Warranty contain some policies and quality standard which already standardize by Indolakto's R\&D, such as the amount of protein or fat in each $\mathrm{mg}$ of several materials.

\section{B. Determining Weight for Each Criteria}

Weight of each criteria were derived from pairwise comparison following AHP methodology. Pairwise comparison was conducted using questionnaire. The respondents were PPIC Manager and Purchasing supervisor. The result of questionnaire were then inputed onto Expert ChoiceTM software.

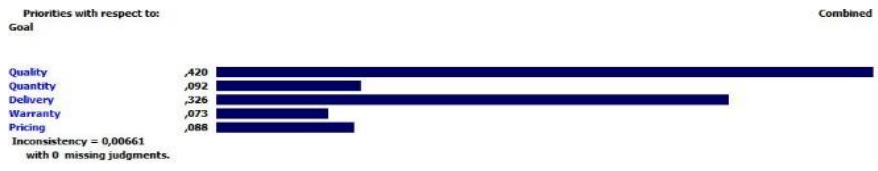

Figure 2. Ranking on main criteria for supplier selection

The inconsistency is 0.00661 . It means, the data is valid because the inconsistency is under 0.1 . Quality $(0.42)$ is the first main criteria that company considerate for selecting supplier. Followed by delivery (0.326), quantity (0.092), pricing (0.088) and warranty (0.073).

There are four main criteria which has their own sub criteria. Figure 3 describe rank of sub criteria based on main criteria quality. The inconsistency for quality sub criteria is 0.08 with 0 missing judgements.

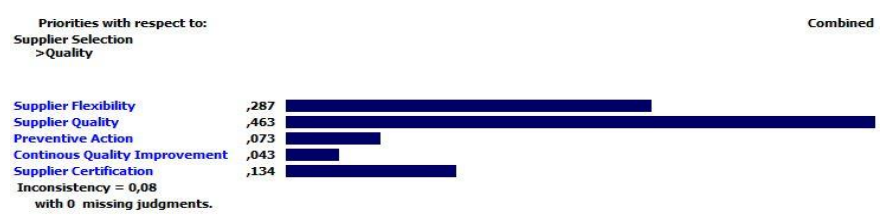

Figure 3. Ranking of sub criteria with respect to main criteria "quality"

Supplier quality (0.463) become the 1 st rank. The 2 nd rank is supplier flexibility $(0.287)$, followed by supplier certification (0.134), preventive action (0.073) and continous quality improvement (0.043).

Delivery only have to sub criteria which are on time delivery and flexibility of supplier delivery. Priorities for those sub criteria is shown in Figure 4.

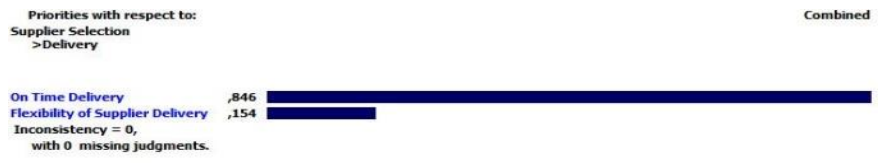

Figure 4. Ranking of sub criteria with respect to main criteria "delivery"

On time delivery is in the 1st place (0.846) and flexibility of supplier delivery is in the 2nd place (0.154).

Priorities with respect to warranty also contain two criteria which are supplier response for under quality product and supplier delivery warranty. It is describe in the Figure 5. below.

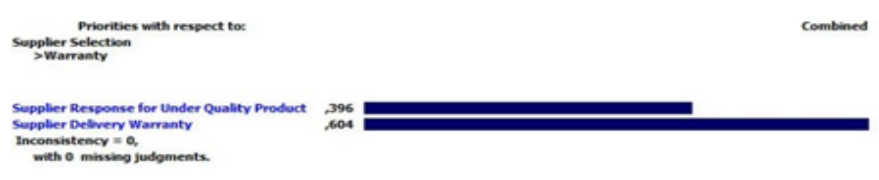

Figure 5. Ranking of sub criteria with respect to main criteria "warranty"

Supplier delivery warranty (0.396) and supplier response for under quality product $(0.604)$. The inconsistency is almost 0 with 0 missing judgements. 
Ranking of sub criteria with respect to pricing criteria have four sub criteria in Figure 6.

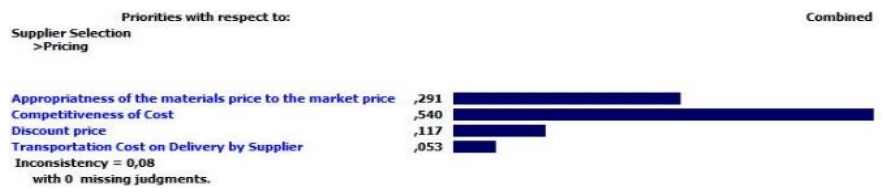

Figure 6. Ranking of sub criteria with respect to main criteria "pricing"

They are competitiveness of cost (0.540), appropriatness of the materials price to the market price $(0.291)$, transportation cost on delivery by supplier (0.053), and discount price if Indolakto buy more than quantity as usual (0.117).

In this process, there are two (2) suppliers who will be evaluated:

Table 2.

Supplier information

\begin{tabular}{ccll}
\hline \hline No. & Supplier Name & \multicolumn{1}{c}{ Location } & $\begin{array}{c}\text { Company } \\
\text { Sized }\end{array}$ \\
\hline Supplier 1 & Maltodextrin A & $\begin{array}{l}\text { Downstream } \\
\text { Industry, } \\
\end{array}$ & Large \\
& & $\begin{array}{l}\text { Surabaya } \\
\text { Surabaya }\end{array}$ & Medium \\
\hline \hline
\end{tabular}

Maltodextrin supplier which code into Maltodextrin A for 1st supplier and Maltodextrin B for 2nd supplier. It is coded due to confidential reason. Indolakto also got TOP BRAND for sweet condensed milk, it means that the supplier for condensed milk, which one of it is maltodextrin supplier has their verified quality. Table 3. shown the global weighted score with their scoring

Table 3. Global weighted score with scoring

\begin{tabular}{|c|c|c|c|}
\hline Main criteria/sub criteria & Weightened & A & B \\
\hline Quality & 0.420 & & \\
\hline Supplier quality & 0.19446 & 0.265 & 0.265 \\
\hline Supplier flexibility & 0.12054 & 0.164 & 0.021 \\
\hline Supplier certification & 0.05628 & 0.076 & 0.076 \\
\hline Preventive action & 0.03066 & 0.042 & 0.042 \\
\hline $\begin{array}{l}\text { Continous } \\
\text { improvement }\end{array}$ & 0.01806 & 0.025 & 0.025 \\
\hline Delivery & 0.32 & & \\
\hline On time delivery & 0.2758 & 0.453 & 0.453 \\
\hline $\begin{array}{l}\text { Flexibility of supplier } \\
\text { delivery }\end{array}$ & 0.0502 & 0.012 & 0.083 \\
\hline Quantity & 0.092 & 0.5 & 0.5 \\
\hline Pricing & 0.08 & & \\
\hline Competitiveness of cost & 0.04752 & 0.420 & 0.060 \\
\hline $\begin{array}{l}\text { Appropriatness of the } \\
\text { materials price to the } \\
\text { market }\end{array}$ & 0.02561 & 0.227 & 0.028 \\
\hline Discount price & 0.0103 & 0.091 & 0.091 \\
\hline $\begin{array}{l}\text { Transportation cost on } \\
\text { delivery by supplier }\end{array}$ & 0.00466 & 0.041 & 0.041 \\
\hline Warranty & 0.07 & & \\
\hline Supplier delivery & 0.04409 & 0.302 & 0.302 \\
\hline $\begin{array}{l}\text { warranty } \\
\text { Supplier response for } \\
\text { under quality product }\end{array}$ & 0.02891 & 0.198 & 0.198 \\
\hline WEIGHTED TOTAL & & 0.556 & 0.444 \\
\hline
\end{tabular}

From all of scoring aspect, it can be concluded that A
Maltodextrin will be choose rather than B Maltodextrin

\section{Sensitivity Analysis - Supplier Selection}

Sensitivity analysis is performed by changing the weight. The dynamic sensitivity will change $\pm 10 \%$ into upward change or downward change to analyze the ranking of supplier will change or not change (robust). Regarding to those result in Figure 4.7. until 4.12. It can be concluded that all of dynamic sensitivty analysis are remain the same.

a. Sensitivity analysis with respect to quality

The rank of supplier is the same whether the dynamic sensitivity of quality is changed in upward mode.

b. Sensitivity analysis with respect to delivery

The rank of supplier will not change (robust) regardless of any value.

c. Sensitivity analysis with respect to warranty

The rank of supplier will not change (robust) regardless of any value.

d. Sensitivity analysis with respect to pricing

The rank of supplier is the same whether the dynamic sensitivity of pricing is changed both in upward and downward mode.

From all of main criteria, it is accepted that A Maltodextrin is better chosen rather than B Maltodextrin.

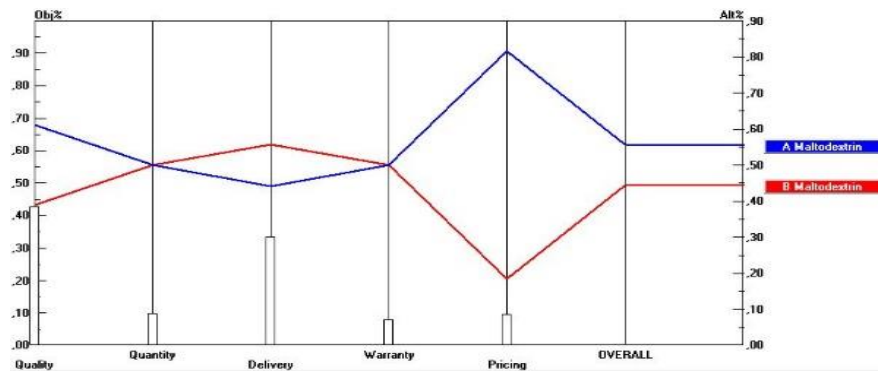

Figure 7. Overall sensitivity analysis

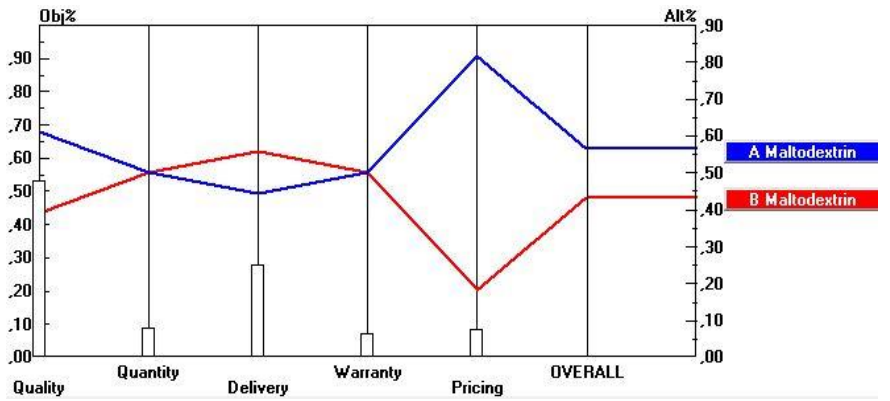

Figure 8 . Sensitivity analysis with respect to quality (upward change)

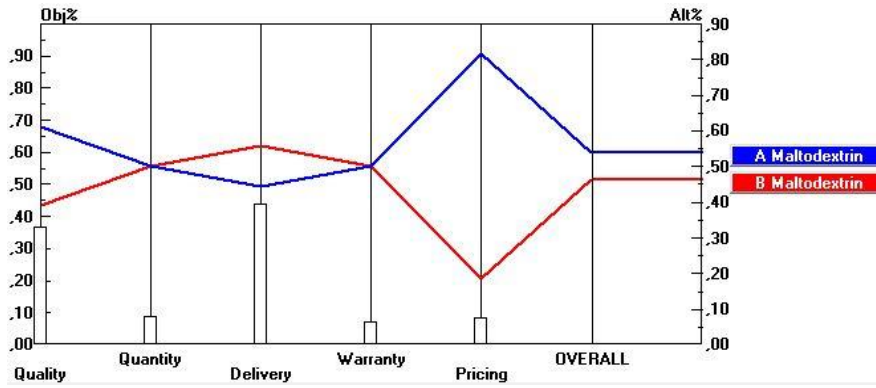

Figure 4.9. Sensitivity analysis with respect to delivery (upward change) 


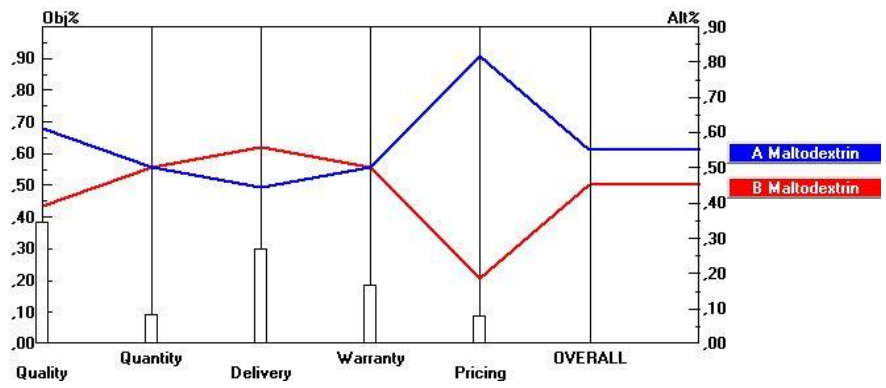

Figure 10. Sensitivity analysis with respect to warranty (upward change)

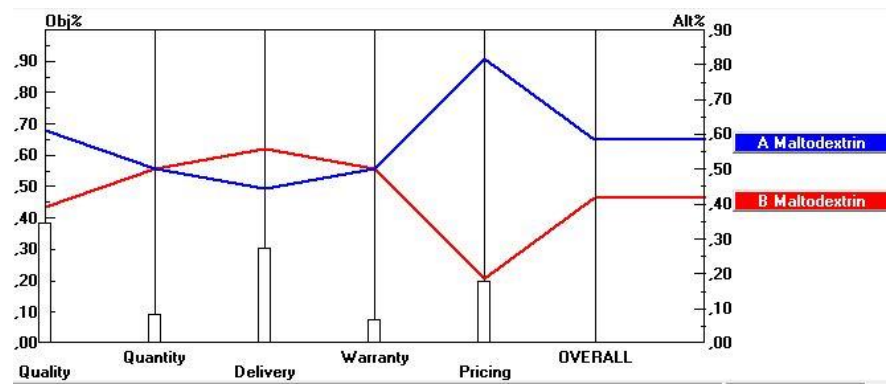

Figure 11. Sensitivity analysis with respect to pricing (upward change)

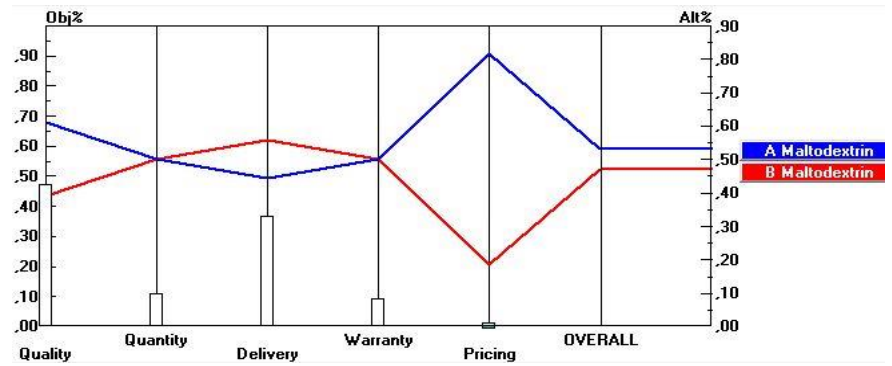

Figure 12. Sensitivity analysis with respect to pricing (downward change)

\section{CONCLUSION}

Regarding to the result of this study, it can be concluded :

a. Selecting the right supplier and evaluating supplier performance is a vital role in the beginning process of supply chain management.

b. The main criterias for supplier selection are quality, delivery, quantity, pricing, and warranty. In addition, the sub criterias are deployed from main criterias based on company requirement.

c. Warranty criteria only used in some conditional situation due to company terms and policies.

d. The result of supplier selection is choosing Maltodextrin A as sweetened raw material supplier. The score for Maltodextrin A is 0.556 and Maltodextrin B is 0.444 .

e. The sensitivity analysis is performed to describe the effect of changing weights in main criteria. All of the sensitivity analysis of supplier selection are stay robust.

\section{BIBLIOGRAPHY}

[1] Aung, M. M. (2014). Traceability in a Food Supply Chain: Safety and Quality Perspectives. Food Control, 172-184.

[2] Pedro Amorim, E. C.-L.-P. (2016). Supplier Selection in the Processed Food Industry under Uncertainty. European Journal of Operational Research.
[3] Chen J, G. Z. (2013). Strategic sourcing in the presence of uncertain supply and retail competition. Production and Operations Management.

[4] Pujawan, I. N. (2010). Supply Chain Management. Surabaya: Guna Widya.

[5] Dani, S. (2015). Food Supply Chain Management and Logistics: From Farm to Fork. UK: CPI Group.

[6] R.R. Pant, G. P. (2015). A Framework for Traceability and Transparency in the Dairy Supply Chain Networks. XVIII Annual International Conference of the Society of Operations Management (SOM-14), 385394.

[7] Global Business Guide Indonesia. (2015). Agriculture . Retrieved from Global Business Guide Indonesia: http://www.gbgindonesia.com/en/agriculture/article/2015/indonesia_s_da iry_industry_needs_to_scale_up_to_meet_local_demand_11207.php

[8] Saaty, T. L. (2008). Decision Making with The Analytic Hierarchy Process. Int. J. Services Sciences, 83-98.

[9] J.H. Trienekens, P. W. (2011). Transparency in complex dynamic food supply chains. Advanced Engineering Informatics, 55-65.

[10] Damian Beil, S. M. (2008). Decision Making with the Analytic Hierarchy Process. Supplier Selection. Int. J. Services Sciences.

[11] Weber, C. C. (1991). Vendor selection criteria and methods. European Journal of Operation Research, 2-18.

[12] Dickson, G. (1966). An analysis of vendor selection systems and decisions. Journal of Purchasing.

[13] Prasanta Kumar Dey, A. B. (2014). Strategic supplier performance evaluation : A case-based action research of a UK manufacturing organisation. Int. J. Production Economics.

[14] COSO. (2004). Enterprise Risk Management - Integrated Framework. Jersey: COSO.

[15] Wu, D. L. (2008). New Frontiers in Enterprise Risk Management. Heidelberg, Germany: Springer-Verlag Berlin Heidelberg.

[16] Flynn, B. S. (1990). Empirical research methods in operations management. Journal of Operations Management, 250-284.

[17] Shapiro. (2014). The Essential Guide to Implementing Vendor Performance Metrics in your Import Supply Chain. Baltimore: Shapiro. 